\title{
The Development Path of Vietnamese Accounting System
}

\author{
Tran Thi Thuong ${ }^{1}$ \\ ${ }^{1}$ Vietnam National University of Agriculture, Hanoi, Vietnam \\ Correspondence: Tran Thi Thuong, Accounting and Business Management Faculty, Vietnam National University \\ of Agriculture, Hanoi, Vietnam. Tel: 84-966-523-199. E-mail: thuongkt48@ gmail.com
}

Received: March 13, 2018

Accepted: April 1, 2018

Online Published: April 10, 2018

doi:10.5539/ijef.v10n5p154

URL: https://doi.org/10.5539/ijef.v10n5p154

\begin{abstract}
After implement "Doi Moi" process in 1986, the Vietnamese accounting system has reformed significantly. To date, the structure of Vietnamese accounting system includes four levels, namely, (1) accounting law, (2) decrees, (3) decisions and Vietnamese Accounting Standards (VASs) and (4) circulars. Particularly, Vietnamese National Assembly promulgated accounting laws in 2003 and 2015. The VASs were promulgated based on the first version of International Accounting Standards (IASs), however until now, the VASs have been not yet amended. Meanwhile IASs have been adjusted regularly and upgraded to IFRSs by International Accounting Standards Board (IASB) since 2001. Moreover, in terms of quantity, Vietnam only promulgated 26 VASs, whereas IASB issued 43 IASs/IFRSs (consist of 27 IASs and 16 IFRSs). Actually, Vietnam became a member of Association of South East Asian Nations (ASEAN) in 1995. On December $31^{\text {st }}$ 2015, the ASEAN set up ASEAN Economic Community (AEC) and as a result, Vietnam is a member of AEC. The one of objectives of AEC is convergence accounting field, through allowance movement freedom of skilled labor in accounting sector within ASEAN members. The research of Backer et al. (2007) mentioned that the accounting harmonization and convergence have became the great topics relevant to international integration in many countries. Therefore, the study shows history and development of Vietnamese accounting law and accounting standards and analyzes the role of each component in Vietnamese accounting system. Especially, the study provides the experience in accounting harmonization from ACE members to evidence the necessary of harmonization with IASs/IFRSs of Vietnam.
\end{abstract}

Keywords: Vietnamese accounting system, accounting standards, VASs, AEC

\section{Introduction}

Before 1986, Vietnam established centrally planned economy based on the Soviet Union's economy model (Huynh et al., 2012). In the centrally planned economy State, all economic activities are controlled, and there are only State ownership and collective ownership. Hence, no market existed in this economy. In that time, Vietnamese accounting system was set up to serve for centralised economy. In 1986, a milestone for Vietnamese economy was marked. Vietnamese economy transformed to market economy with socialist orientation and integrated with the area economy and global economy. It was called "Doi Moi" process. After 1986, the Vietnamese economy grew rapidly with increase of foreign investment and rapid growth of the private economic sector (Huynh et. al., 2012). Through 30 years of "Doi Moi", Vietnam has gained significant achievement (Nguyen, 2017). Particularly, during period 1986-2016, Gross Domestic Product (GDP) of Vietnam went up statistically from 26,337 billion USD to 202,616 billion USD with average growth rate $6.43 \%$; Gross National Income (GNI) per capital increased from 220 USD in 1989 to 2,050 USD in 2016 (Worldbank Database, 2017).

Therefore, Vietnamese accounting system also transformed significantly toward to harmonize with international accounting. Following this trend, Vietnamese National Assembly promulgated accounting laws in 2003 and 2015; Ministry of Finance (MOF) issued 26 VASs based on IASs system during period 2001-2005. This VASs system is totally suitable with Vietnamese economy at that time. However, there is a significant gap between VASs and IASs/IFRSs today (Huynh et. al., 2012). Especially, on December $31^{\text {st }} 2015$, the ASEAN built ASEAN Economic Community (AEC). The objective of AEC is to transform ASEAN into a region with free movement of goods, services, investment, skilled labor and a free flow of capital. Especially, provisions for skilled labor movement within ASEAN principally revolve around Mutual Recognition Agreements (MRAs), which allow for a worker's skills, experiences and accreditations to be recognized across ASEAN, permitting them to work outside their home country. Additionally, accountancy service is one of sector is mentioned in MRAs. As such, completing the accounting standards in each AEC country in convergence and harmonization with IASs/IFRSs 
(Phan, 2016) plays an important role to conduct MRAs. Hence, in the context of globalization of accounting, Vietnam has to conduct integration process with IASs/IFRSs.

This study focuses on description history and development of Vietnamese accounting law and accounting standards in section 2. Particularly, this study analyzes the role of each component in Vietnamese accounting system in the third section. After that, this study summaries experience in accounting convergence from members of ASEAN Economic Community (AEC) in section 4. The last section is showed as the conclusion of this study.

\section{History and Development of Vietnamese Accounting Law and Accounting Standards}

According to Chu (2004), his study about Vietnam accounting changes in a transition economy showed that the history of Vietnam accounting is separate into two main periods: historical (before 1981) and reformed (from 1981 to present). The accounting reform was separated into three periods, namely, initial steps (1981-1990), radical accounting reform (1991-1996) and the present program (1996-present). The author also indicated the history and development of Vietnam accounting was greatly affected by foreign countries like France, Soviet Union and China. Following the view of Phi (2014), the Vietnam accounting history was separated into two main periods including the before and after 2003 - when Vietnamese Accounting law has been appeared. Meanwhile, Nguyen (2015) said that there are four stages in the development process of Vietnam accounting from 1975 when Vietnam gained independence - to 2015, specifically, 1975-1985, 1986-1990, 1990-2003 and 2003-2015. Therefore, depending on the topic of research, the stages of Vietnam accounting history are divided based on different criteria. In this article, the emphasis summaries the development process of Vietnamese accounting system in accordance with the appearing time of Vietnamese accounting law and VASs. Therefore, the Vietnamese accounting history was separated into four main periods including before 1988, 1988-2003, 2003-2015 and after 2015. Especially, according to Nguyen (2015), in parallel with the development of the economy, accounting system also often has changed to become a suitable management tool.

Before 1988, the accounting system served for state economic management of the centrally planned economy with main task of monitoring information. This economy model was influenced strongly by the Soviet Union's economy model. This economy focused on four main targets, namely, (1) totally removing private ownership, (2) creating the socialist public ownership which includes state ownership and collective ownership, (3) completely eliminating market mechanisms and (4) setting the management system of the centrally subsidized, planned economy. During this time, the task of accounting system was protection and utilization of the assets by state and collective. The accounting system was based on Decree No.93 "State Enterprises Charter" (dated April 18 ${ }^{\text {th }}$ 1977) and Decision No.223-CP “The Financial Statement System" (dated December $1^{\text {st }}$ 1970). In 1986, Vietnam's shift from a centrally planned to a state regulated and market oriented economy has modified and created new policies and strategies on economic fields (Tran, 2015). The shift, known as the "Doi Moi" process (Tran, 2015). Hence, since 1986, the private enterprises and the non-state businesses were recorgnized as a part of Vietnamese economy, and the accounting system was reformed to adapt with these significant economy changes. There are two main reasons for this change. First of all, internal factor, after 10 years independent, Vietnam's economy really fell into crisis with food shortages, low efficiency industry sector and so on. The other reason is the collapse of socialism in the Soviet Union and Eastern Europe; and the development of the science and technology revolution. To exist, the tendency of socialist countries was economic reforms, for example, economic reforms of China in 1978, the reforms of the Soviet Union in 1985.

During period 1988-2003, the accounting systems had transferred to serve to market economy; and the accounting system had been reformed to reach the harmony with IASs and to serve the integration in the world economy (Nguyen, 2015). The first marked important point in the period was the birth of Ordinance on Accounting and Statistics (dated May $10^{\text {th }} 1988$ ) effective from October $1^{\text {st }} 1988$ by Vietnamese Government. This was the first and highest accounting legal document of Vietnam at that time. This Ordinance suggested general guidelines about initial records of transactions, accounts and accounting books, inventory of assets, accounting reports and accounting inspection. Based on this Ordinance, in March 1989, the Government promulgated the Charter of State Accountancy Organization and the Charter of Chief Accountant, and MOF issued Decision No.212/TC-CDKT dated December $15^{\text {th }} 1989$ detail instruction the accounting system regime. On November $1^{\text {st }} 1995$, MOF continued to issue Decision No.1141-TC/QD/CDKT of promulgating the enterprises' accounting regime for state businesses and other types of businesses; and Decision No.1177/TC/QD/CDKT (dated December $23^{\text {rd }} 1996$ ) accounting regime for small and medium entities. Specially, on October $1^{\text {st }} 1994$ the Vietnam Accounting Association (VAA) was born to mark the presence of accounting and the professional accounting profession in Vietnam. After that, VAA participated as member of the International Federation of Accountants (IFAC) and the ASEAN Federation of Accountants (AFA) respectively 
in 1996 and 1998. Especially, in this period, big foreign owned auditing firms (Deloitte \& Touche, Ernst \& Young (E\&Y), KPMG and PricewaterhouseCoopers $(\mathrm{PwC})$ ) played main roles to import knowledge of accounting market into Vietnam directly (Chu, 2004). The remarkable second point was the appearances of the ten VASs in 2001 and 2002 by the Vietnamese Accounting Standard Board (VASB). VASB consists of 13 members who are not government officers but not completely independent from the Vietnamese government (Nguyen et al., 2012). This organization was established by MOF and depended on MOF. Notably, the contents of these VASs were built on the basis of applying the principles of IASs in accordance with the situation and characteristics of Vietnam, and on the basis of setting the stage for the development of institutional accounting applied to specific objects. The first package of VASs was released based on the Decision No.149/2001/QD-BTC - which included the acounting standards about Inventories (VAS02), Tangible Asset (VAS03), Intangible Asset (VAS04) and Revenue and Other Income (VAS14). The next six VASs was promulgated based on the Decision No.165/2002/QD-BTC - which included the accounting standards about General Standards (VAS01), Leases (VAS06), Effects of Changes in Foreign Exchange Rates (VAS10), Construction Contracts (VAS15), Borrowing Costs (VAS16) and Cash Flow Statement (VAS24). However, at that time, it was difficult for the accounting staffs to apply ten VASs, the cause was lack of uniform accounting regulation occurred in the domestic market (Phi, 2014) and the contradictory between VASs and the Ordinance on Accounting and Statistics. That is why Vietnam government needs to change the accounting law. Therefore, in 2003, the highest power of regulation the law of accounting - was launched.

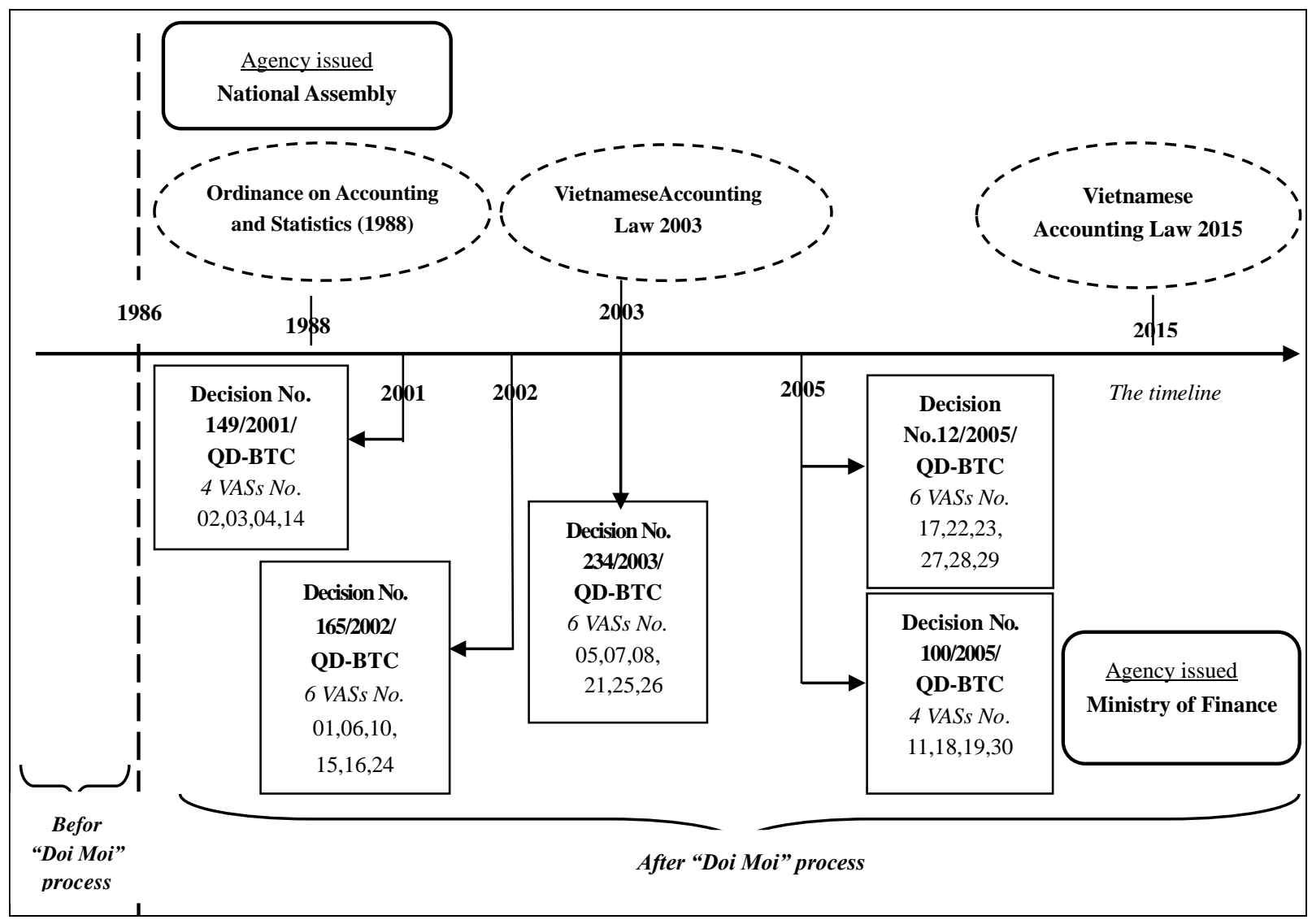

Figure 1. The timeline of Vietnamese accounting law and Vietnamese Accounting Standards (VASs)

Source: Own Contribution, 2017.

In the third period (2003-2015), political institutions had been virtually stable based on leadership of Vietnamese Communist Party. During this period, Vietnamese accounting system had developed significantly and strongly on both quality and quantity (Nguyen, 2015). Based on the IASs and the requirement of market economy, the legal system of Vietnamese accounting was set up and improved gradually (Nguyen, 2015). This legal system was classified into four levels, namely, accounting law, decrees, accounting standards and decisions and circulars. In Vietnam, the accounting legal framework has been maintained and amended by the National Assembly, MOF, the Department of Accounting and Auditing Policy, and the VASB (Phi, 2014; Dezan Shira \& Accociates, 2016). 
Based on Vietnam's Law on Accounting, issued by the National Assembly, MOF has been entrusted significant responsibility for accounting regulation. Under MOF, the Department of Accounting and Auditing Policy has formed the VASB to improve and issue standards. According to Huynh et al. (2012) and Nguyen et al. (2012), the legal Vietnamese accounting framework is constructed the strictly hierarchical levels like pyramid symbol. The highest level is accounting law which has the highest legal status. The next level is decrees, and then to decisions and accounting standards. The lowest hierarchical level is circulars. Normally, the lower documents will be used to explain clearly the higher documents.

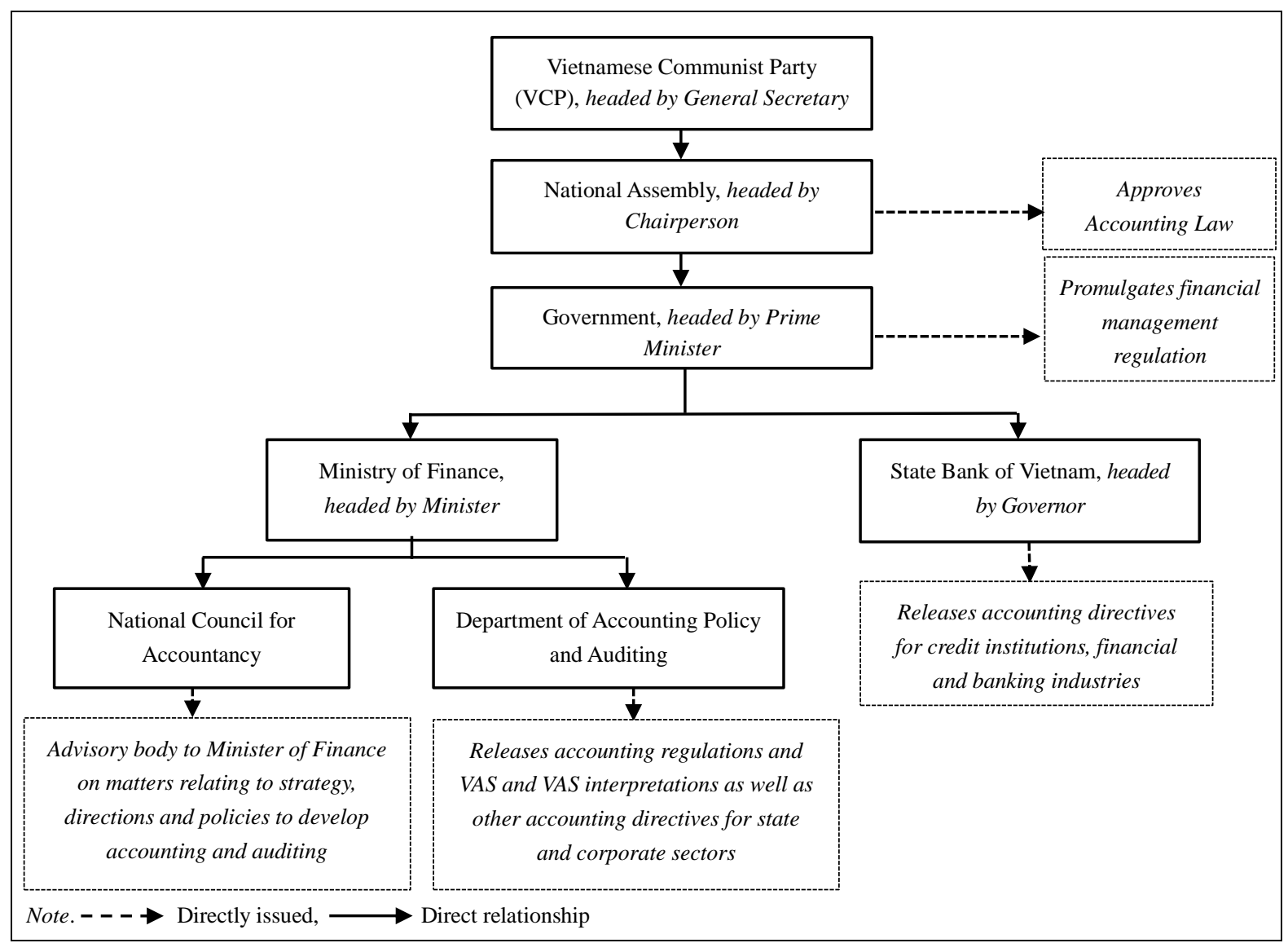

Figure 2. Detail the structure of three sources of financial and accounting law and regulations in Vietnam (1992 Constitution)

Source: Thanh, 2011.

The first marked important point of the period 2003-2015 was the appearance of Accounting Law No.03/2003/QH11 (Accounting Law 2003) which was issued by the National Assembly in $17^{\text {th }}$ June 2003 with effective from January $1^{\text {st }}$ 2004. Accounting Law 2003 replaced Ordinance on Accounting and Statistics 1988 and improved the legal framework for accounting work during 15 past years. According to Nguyen (2015) the appearance of Accounting Law 2003 was made a positive impact on economy and society. Firstly, this law created the legal basis for Vietnamese Government and MOF to issue decrees, accounting standards, and circulars which maked a comprehensive accounting legal framework throughout the country. Secondly, organization of the accounting system of Vietnam has been more clearly defined, and separated into four areas, namely, state accounting, corporate accounting, bank accounting, cooperative accounting. Thirdly, it contributed to improve the market mechanism under the management of the State, and in accordance with international integration. Lastly, the organization of specialized accounting training has been improved, notably, academy and universities have educated the specialized accounting course in undergraduate and graduate level. 


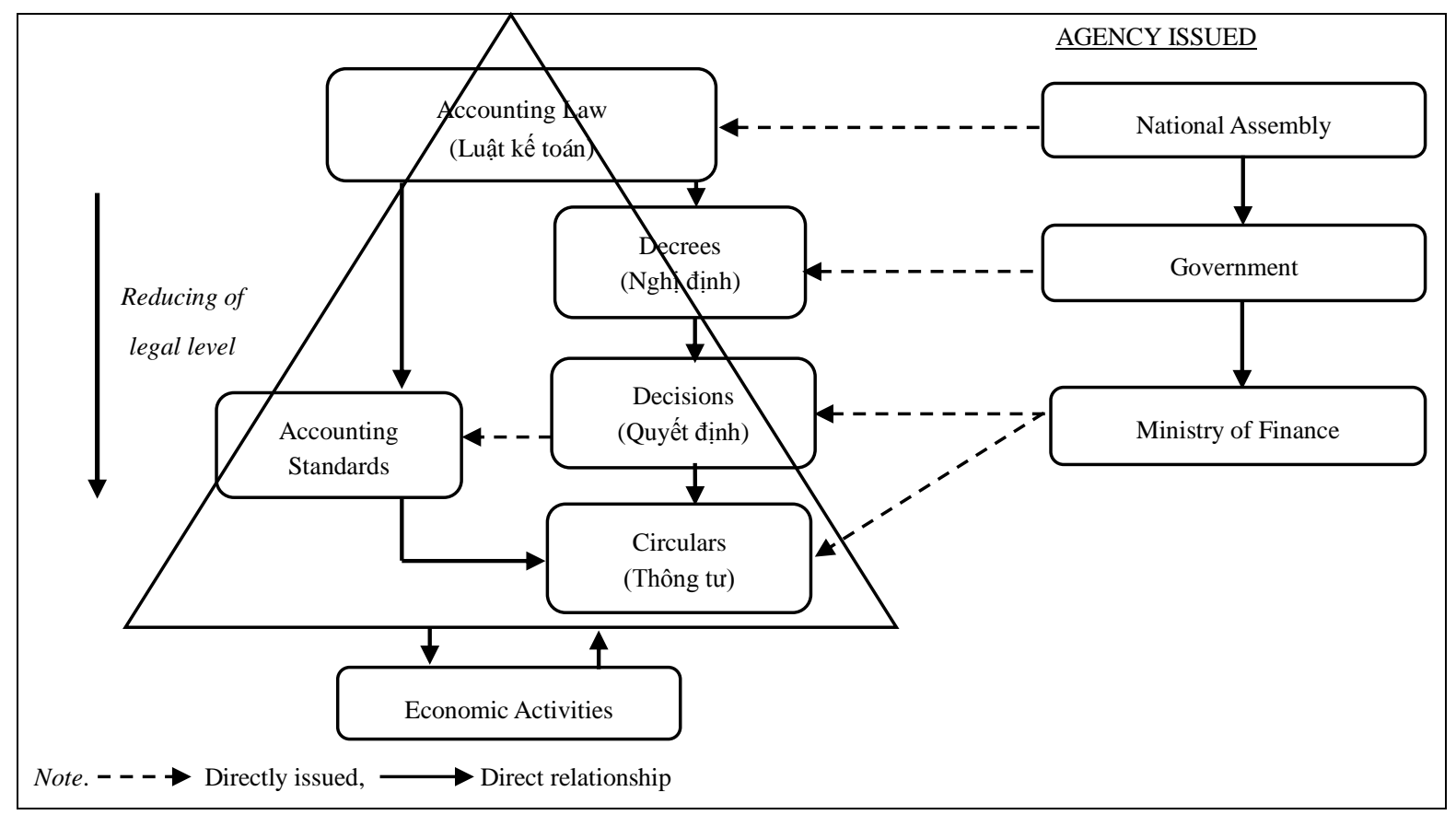

Figure 3. Structure of Vietnamese accounting system

Source: Own Contribution, 2017.

The next important point of the period 2003-2015 was the birth of 16 VASs which were issued by MOF to adapt with international economic integration and harmonize with IASs. The third package of VASs was promulgated based on the Decision No.234/2003/QD-BTC - which included six accounting standards, namely, Investment Property (VAS05), Investment in Associated Companies (VAS07), Financial Information About the Venture Capital Contributions (VAS08), Presentation of Financial Statement (VAS21), Consolidated Financial Statement and Accounting for Investment in Subsidiaries (VAS25) and Information on Related Parties (VAS26). In February and December 2005, MOF enacted the forth and the fifth packages of VASs. The forth package of VASs was enacted based on the Decision No.12/2005/QD-BTC - which included six accounting standards, namely, Income Taxes (VAS17), Disclosures in Financial Statement of Banks and Similar Financial Institutions (VAS22), Events after the Balance Sheet Date (VAS23), Interim Financial Reporting (VAS27), Segment Reporting (VAS28) and Changes in Accounting Policies, Accounting Estimate and Errors (VAS29). The last package of VASs was issued base on the Decision No.100/2005/QD-BTC - which included four accounting standards, namely, Business Combination (VAS11), Provisions, Contingent Assets and Liabilities (VAS18), Insurance Contract (VAS19) and Earning Per Share (VAS30).

After 2015, the accounting system has continued to develop significantly to reach the harmony with IASs/IFRSs and to serve the integration in the world economy. Particularly, the National Assembly issued Accounting Law No.88/2015/QH13 (Accounting Law, 2015) with effective from January $1^{\text {st }} 2017$ to supersede Accounting Law 2003. Because Accounting Law 2003 exposed some items not suitable with the development of the economy like only using cost principle and so on. The Accounting Law 2015 includes six Chapters and 74 Articles. It regulates the contents of accounting work, the organisation of accounting system, accountants, accounting services, state management of accounting and accounting professional organisations. In comparison with Accounting Law 2003, Accounting Law 2015 mentions about the fair value concept which is a major change in accounting principles. (PwC Vietnam NewsBrief, 2016). It means that assets and liabilities must be revaluated at fair value at the financial reporting date. Specifically, financial instruments must be measured at fair value; monetary items denominated in foreign currencies are measured at actual exchange rates and assets or liabilities which have frequent volatility in value are revaluated at fair value. However, the fair value revaluation of assets and liabilities must based on reliable measurements (as three levels of inputs in IFRS 3). If no reliable measurements, the assets and liabilities are measured at historical cost.

Although VASs were promulgated, Vietnamese accounting practices are still mainly based on decisions and circulars - a "rules - based" regime (Huynh et. al., 2012). These legal documents described detaily guiding on using chart of accounts, recording transaction in accounting books and presenting of financial statements. Under 
the pressure of international liberazation, accounting legal framework of Vietnam has been reformed, to date, it governed by Accounting Law 2015 and 26 VASs. These VASs range from general guidance on the segmentation of financial reports to more detailed regulations on the technical subject issues such as the calculation of contingent assets and liabilities (Dezan Shira \& Accociates, 2016). However, VASs were promulgated from 2001-2005, in fact IASs have been updated, due to changing economic and financial conditions, but VASs has not been amended or supplemented in time and currently, this is the big issue for accounting legal framework of Vietnam.

\section{The Role of Each Component in Vietnamese Accounting System}

The legislative structure of Vietnamese accounting system reflects the hierarchical control which was mentioned in the research "Modes of regulation in advanced capitalism: locating accountancy in four countries" by Puxty et. al. (1987). To understand clearly about the structure of Vietnamese accounting system, analyzation the role of each inside component is very necessary.

Accounting law is the highest legal document for the performance of accounting work and it was issued by National Assembly, governing all accounting and auditing activities in Vietnam. Thanh (2011) mentioned that the accounting law is marked as a significant accomplishment in the overall accounting reform process. Micheline and Nguyen (2007) indicated the top principles of Vietnamese accounting law consist of the presentation of reliable economic information, the designation of MOF as the body responsible for accounting standards setting and monitoring, the organization and reliability of accounting records, the separation between financial accounting and management accounting and finally auditing requirements for publicly listed companies and foreign invested enterprises. The law provides the legal basis for the Government and MOF promulate lower legal documents like decrees, decisions and circulars. The above documents have created comprehensive and uniform legal framework of accounting for application in whole country. The accounting law confirms that accounting is one of the tools of economic and financial management, and accounting plays an important role in governance of the national economy (Thanh, 2011). The Law is applicable to all entities in Vietnamese economy consisting of state agencies, professional units, business enterprises of all economic sectors, branches and representative offices of foreign enterprises and cooperatives (The National Assembly, 2003). Under the provisions of the accounting law, the accounting law includes the following contents: accounting vouchers, chart of accounts and accounting books, financial reports, accounting inspection, assets inventory and accounting records archival, and accounting work in cases of dissolution, merger, acquisition, conversion of ownership form, bankruptcy and termination of operations. The chart of accounts includes two parts, namely, (1) Balance sheet accounts (Class 1 - Current assets, Class 2 - Fixed assets, Class 3 - Liabilities, Class 4 - Owner's equity) and (2) Operating accounts (Class 5 - Revenue, Class 6 - Production and operating expenses, Class 7 - Other revenue, Class 8 - Other expenses and Class 9 - Determination of operating results). In additional, the Accounting Law adds the Code of Professional Ethics. Accordingly, accounting professional ethics standard includes regulations and guidelines on the principles and contents of application of professional ethics standards to accountants, practicing accountants and business accounting services enterprises. The addition of regulations on accounting professional ethics helps accountants and accountancy service providers to ensure compliance with the general regulations of the accounting profession.

The second level consistes of mandatory regulations regarding the conceptual framework of accounting and financial management, endorsed by the Vietnamese Government. It was known as a decree (nghi định). The decree has a role of guiding in detail some articles of the accounting law, specifically, the content of accounting work, the organization of accounting apparatus and accountants, accounting services business operations, supplying cross-border accounting services and accounting professional. Currently, the new decree in guiding accounting law is Decree No.174/2016/ND-CP dated $30^{\text {th }}$ December 2016 effective from January $1^{\text {st }} 2017$. This decree replaced Decree No.128/2004/ND-CP dated 31 ${ }^{\text {st }}$ May 2004 guiding the Law on Accounting applicable in the field of state accounting and Decree No.129/2004/ND-CP dated May $31^{\text {st }} 2004$ guiding the Accounting Law applicable in business activities.

The third level includes decisions and accounting standards which are announced and issued by MOF. The fourth level comprises circulars and guidelines on the accounting regime issued by the MOF to accountants and accounting and auditing practitioners. Since the VASs system was born by decisions of MOF from 2001, it has contributed to meet the requirements of integration process and opened up the accounting services in Vietnam. VASs system was enacted the first version of IASs/IFRSs and be consistent with Vietnamese economic conditions. The structure of each VAS consists of following sections, namely, purpose of the standard, scope of the standard, definitions used in the standard and main contents which includes principles, methods, requirements for making and presenting on financial statements. Nguyen (2014) confirmed that, the practical 
application of VASs system is quite high. The objective of VASs system gives guidelines to exactly reflect business operation on financial statement. Especially, based on VASs system these financial statements of different enterprises in different sectors can be compared easily. Thus, the drafting and issuance of accounting standards unify the accounting activities in a country. In addition, the VASs system also statistically contributes to develop Vietnam's stock market. Particularly, in Vietnam, the State Securities Commission was established under Decree No.75/ND-CP dated November $28^{\text {th }} 1996$, Ho Chi Minh City Securities Trading Center and Hanoi Securities Trading Center were opened operation respectively in 2000 and 2005. Ho Chi Minh Stock Exchange and Hanoi Stock Exchange were officially opened respectively in 2007 and 2009. Therefore, to develop the stock market, the listed companies are required to disclose accounting information and financial reports honestly and publicly (Nguyen, 2014). Hence, the VASs system ensures consistency in accounting records, presentation and explanation of financial statements of enterprises. Moreover, the VASs system was translated into english language to serve the foreign investors. Simultanously, the VASs system also has created international recognition of Vietnam in accounting process of integration (Nguyen, 2014). However, until now the VASs system does not yet have new version.

Simultanously, corresponding to each moment, MOF also promulgated detail decisions and circulars on the accounting regime. According to Article 3 of Accounting Law 2015, accounting regime is accounting regulations and accounting guidelines in a specific field or specified work which are promulgated by the State management agency in accounting or organizations authorized by the state management agency in accounting. For different economic organization groups, namely, enterprises, state administrative unit, cooperatives and securities enterprises and so on MOF issues diffterent accounting regimes. Each accounting regime consists of accounting account system, financial reporting regime, accounting voucher regime, accounting book regime and accounting forms. These accounting regimes usually have updated to catch up the transform of Vietnamese economy and the development of international accounting. In Vietnam, all accountants often have used these decisions and circulars as detail guidelines for accounting practices in enterprises. Particularly, from 1986 to now, the transformation of accounting regimes for some main organization groups in different periods is shown in below table.

Table 1. The transformation of accounting regime for some main organization groups from 1986 to now

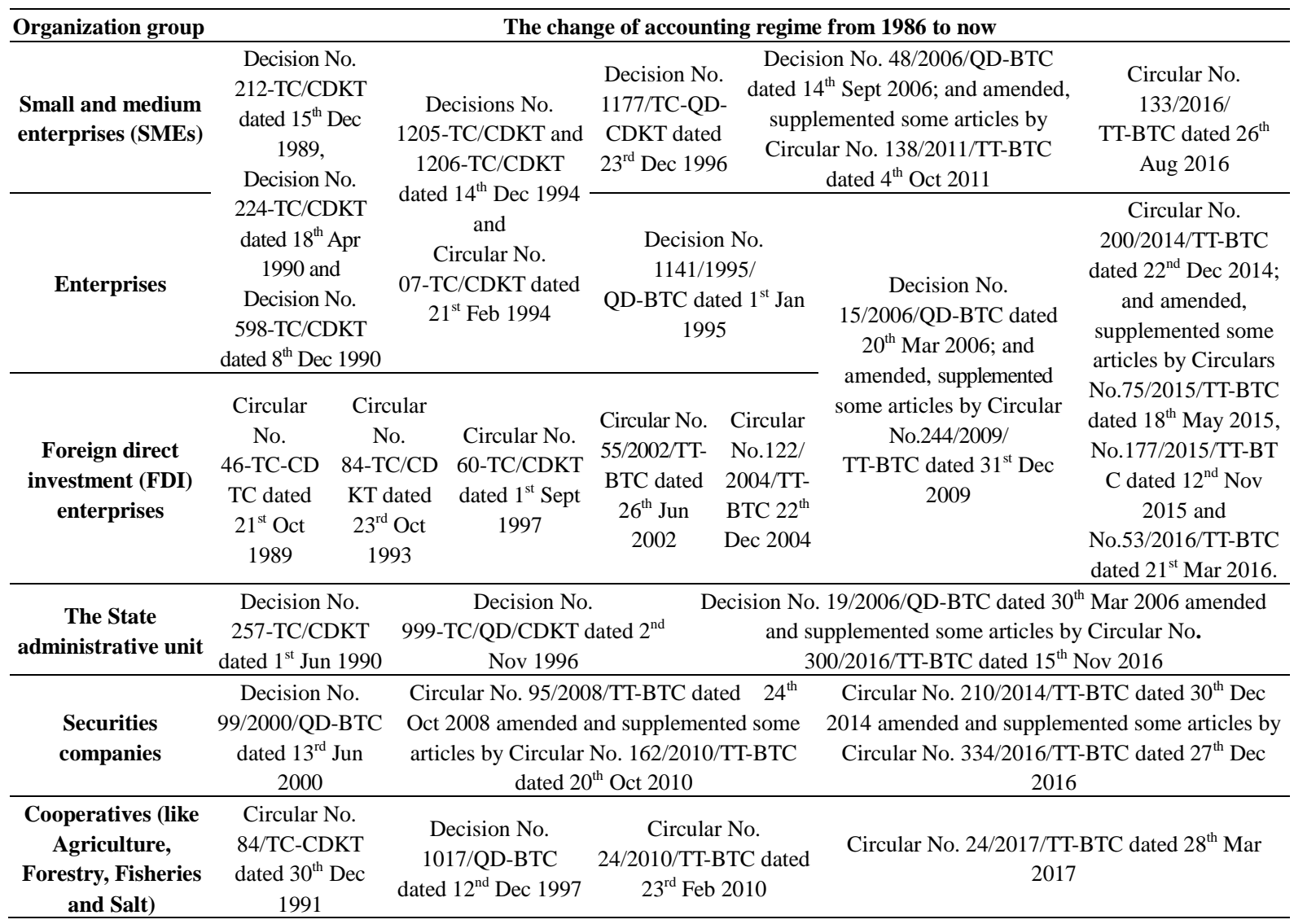

Source: Owned Contribution, 2017. 


\section{Experience in Accounting Convergence from Members of ASEAN Economic Community (AEC)}

The precursor of the ASEAN is an organization called the Association of Southeast Asian Nations (ASA). The ASA was a union formed in 1961, comprising The Philippines, Malaysia and Thailand. The ASEAN is as known Association of Southeast Asian Nations. The ASEAN was established on August $8^{\text {th }} 1967$ by five countries, namely, Indonesia, Malaysia, The Philippines, Singapore and Thailand. After that, the organisation's membership has expanded to include Brunei Darussalam, Cambodia, Laos, Myanmar and Vietnam. As such, there are ten members in the ASEAN. Its principal aims consist of accelerating economic growth, social progress and sociocultural evolution among its members, alongside the protection of regional stability and the provision of a mechanism for member countries to resolve differences peacefully.

On December $31^{\text {st }} 2015$, the ASEAN established ASEAN Economic Community (AEC). The objective of AEC is to transform ASEAN into a region with free movement of goods, services, investment, skilled labor and a free flow of capital. Especially, provisions for skilled labor movement within ASEAN principally revolve around Mutual Recognition Agreements (MRAs), which allow for a worker's skills, experiences and accreditations to be recognized across ASEAN, permitting them to work outside their home country. ASEAN currently has MRAs in place for six sectors and framework agreements in place for two more. MRAs exist for the following occupations, (1) engineering, (2) nursing, (3) architectural, (4) medicine, (5) dentistry, (6) tourism, (7) surveying framework and (8) accoutancy framework (Phan, 2016). Hence, regulatory uniformity in the accountancy sector plays an important role in the implementation MRAs. Therefore, to implement the MRAs, completing the accounting standards in each AEC country in convergence and harmonization with IASs/IFRSs ((Phan, 2016).

Table 2 summaries the adoption of IASs/IFRSs of each member in AEC. The adoption of IASs/IFRSs of ten countries in AEC are classified into three groups (Phan, 2016). In the first group, some AEC member countries have accepted the application of the entire content of the IASs/IFRSs, such as Brunei Darussalam, Indonesia, Malaysia, Cambodia and Lao PDR. In the second group, countries issued their national accounting standards based on IASs/IFRSs and have updated regularly as the Philippines and Singapore. Meanwhile, in the last group, countries enacted their national accounting standards based on IASs/IFRSs and are almost unchanged with new features like Myanmar, Thailand and Vietnam.

Table 2. The summary of adoption IAS/IFRS in each country members of AEC

\begin{tabular}{|c|c|c|c|}
\hline \multirow{2}{*}{ No. } & \multirow{2}{*}{ Country } & Extent of IAS/IFRS application & \multirow{2}{*}{$\begin{array}{c}\text { Extent of IAS/IFRS for SMEs } \\
\text { application }\end{array}$} \\
\hline & & $\begin{array}{ll}\text { Domestic public companies } & \text { Foreign companies }\end{array}$ & \\
\hline 1 & $\begin{array}{l}\text { Brunei } \\
\text { Darussalam }\end{array}$ & $\begin{array}{l}\text { There is no stock exchange in Brunei Darussalam. There is no stock exchange in } \\
\text { The country adopted full IFRSs for financial Brunei Darussalam. } \\
\text { institutions, like banks, financial institutions, } \\
\text { insurance and takaful companies effective January } \\
1^{\text {st }} 2014\end{array}$ & $\begin{array}{l}\text { The IFRSs for SMEs is under } \\
\text { consideration. }\end{array}$ \\
\hline 2 & Cambodia & $\begin{array}{l}\text { IFRSs adopted without modification as Cambodian IFRSs are required for listings } \\
\text { International Financial Reporting Standards by foreign companies. } \\
\text { (CIFRSs) are required for listed entities, but } \\
\text { mandatory adoption for banks, insurance } \\
\text { companies and microfinance institutions deferred } \\
\text { to January } 1 \text { st } 2016\end{array}$ & $\begin{array}{l}\text { Only SMEs subject to a statutory } \\
\text { audit are required to use IFRSs for } \\
\text { SMEs. }\end{array}$ \\
\hline 3 & Indonesia & $\begin{array}{l}\text { Indonesia has not adopted IFRSs for reporting by All foreign companies whose } \\
\text { domestic companies. Indonesian Financial securities trade in a public } \\
\text { Accounting Standards (IFASs) are based on market are required to use } \\
\text { IFRSs that were effective at January } 1^{\text {st }} 2009 \text { with IFASs. } \\
\text { some modifications. Indonesia has been } \\
\text { converging IFASs toward IFRSs, but without a } \\
\text { plan for full adoption of IFRSs. }\end{array}$ & \\
\hline 4 & Lao PDR & $\begin{array}{l}\text { The IFRS Foundation has yet to release the jurisdictional profile of Lao PDR, bu } \\
\text { Young (2014), Lao PDR plans to fully adopt IFRS in } 2014 \text { and to cover the listed col }\end{array}$ & $\begin{array}{l}\text { ut based on the research of Ernst \& } \\
\text { mpanies. }\end{array}$ \\
\hline 5 & Malaysia & $\begin{array}{l}\text { Public companies are required to use the IFRSs are permitted for } \\
\text { Malaysian Financial Reporting Standards listings by foreign companies } \\
\text { (MFRSs) Framework, which is substantively } \\
\text { equivalent to IFRSs. }\end{array}$ & $\begin{array}{l}\text { SMEs are permitted to use the } \\
\text { Malaysian Private Entities } \\
\text { Reporting Standard (MPERSs), } \\
\text { which is substantively equivalent to } \\
\text { the IFRSs for SMEs except for the } \\
\text { requirements for property } \\
\text { development activities plus some } \\
\text { terminology changes. }\end{array}$ \\
\hline
\end{tabular}




\begin{tabular}{|c|c|c|c|}
\hline \multirow{2}{*}{ No. } & \multirow{2}{*}{ Country } & Extent of IAS/IFRS application & \multirow{2}{*}{$\begin{array}{c}\text { Extent of IAS/IFRS for SMEs } \\
\text { application }\end{array}$} \\
\hline & & $\begin{array}{ll}\text { Domestic public companies } & \text { Foreign companies } \\
\end{array}$ & \\
\hline 6 & Myanmar & $\begin{array}{l}\text { Public companies and financial institutions are There are no foreign companies } \\
\text { required to use Myanmar Financial Reporting whose securities trade in a } \\
\text { Standards (MFRSs), which are substantively public market in Myanmar. } \\
\text { identical to the } 2010 \text { versions of IFRSs. }\end{array}$ & $\begin{array}{l}\text { Myanmar has adopted the IFRSs for } \\
\text { SMEs as the MFRSs for SMEs. } \\
\text { SMEs are permitted to use the } \\
\text { MFRSs for SMEs or full MFRSs. }\end{array}$ \\
\hline 7 & $\begin{array}{l}\text { The } \\
\text { Philippines }\end{array}$ & $\begin{array}{l}\text { Philippines has adopted full IFRSs as Philippine IFRSs adopted as PFRSs are I } \\
\text { Financial Reporting Standards (PFRSs) with required. } \\
\text { several limited modifications to IFRSs. }\end{array}$ & $\begin{array}{l}\text { Philippines has adopted the IFRSs } \\
\text { for SMEs as the PFRSs for SMEs } \\
\text { without any modifications. }\end{array}$ \\
\hline 8 & Singapore & $\begin{array}{l}\text { Listed companies are required to use Singapore All foreign companies listed on } \\
\text { Financial Reporting Standards (SFRSs), which the Singapore Exchange are } \\
\text { are substantially converged with IFRSs. permitted to apply IFRSs under } \\
\text { However, with permission of the securities the Listing Rules. Specifically, } \\
\text { regulator, listed companies may use IFRSs as foreign companies whose equity } \\
\text { issued by the Board. } \\
\text { securities have a primary listing in } \\
\text { Singapore are required to apply } \\
\text { SFRSs, IFRSs or US GAAP, } \\
\text { while those with a secondary } \\
\text { listing are required only to } \\
\text { reconcile their financial } \\
\text { statements to SFRSs, IFRSs or } \\
\text { US GAAP. }\end{array}$ & The IFRSs for SMEs is permitted \\
\hline 9 & Thailand & $\begin{array}{l}\text { Thai Accounting Standards (TASs) are required. TASs are required. } \\
\text { TASs are substantially converged with IFRSs, } \\
\text { though the financial instruments Standards that } \\
\text { are part of IFRSs have not yet been adopted. } \\
\text { TASs include several national financial } \\
\text { instruments standards that differ from IFRSs. }\end{array}$ & $\begin{array}{l}\text { The IFRSs for SMEs is permitted, } \\
\text { but currently no foreign companies } \\
\text { are traded on the Stock Exchange of } \\
\text { Thailand. }\end{array}$ \\
\hline 10 & Vietnam & $\begin{array}{l}\text { No. Vietnam has not adopted IFRS Standards. All No. } \\
\text { listed companies must apply VASs which are } \\
\text { based on IASs issued up to 2003. IFRS required } \\
\text { for state-owned banks and permitted for } \\
\text { commercial banks. }\end{array}$ & VASs are required. \\
\hline
\end{tabular}

Source: Ernst and Young (2014) and The IFRS Foundation (2017). Available at http://www.ifrs.org.

Phan (2016) also mentioned IASs/IFRSs adoption for the Small-Medium Enterprise (SMEs) of countries in AEC. There are four countries that have adopted fully IFRSs for SMEs, namely Cambodia, Lao PDR, Myanmar and the Philippines. Meanwhile, four countries have issued and adopted accounting standards system for SMEs like Indonesia, Malaysia, Singapore and Thailand. Brunei Darussalam tends to be promugated while Vietnam has not yet issued a separate accounting standard for SMEs.

As such, based on the brief discussion above, to date, Vietnam ranks the lowest level of the IASs/IFRSs implementation status. Currently, many countries in the world are moving towards the trend of converging IFRSs (Dao \& Dang, 2017). In the context of globalization of accounting, Vietnam has to conduct integration process with IFRSs. It means that Vienam needs to reform accounting sector in accordace with the convergence with IASs/IFRSs. According to Dao and Dang (2017), Vietnam can be consider three models to adopt IASs/IFRSs. The first model is full replacement VASs by IASs/IFRSs, Vietnam only issues standards for special accounting issues which have not yet mentioned in IASs/IFRSs. This model is known as convergence by applying direct IFRS (full or near-full convergence). The second model is known as convergence by alignment with IFRS in reciprocal way. The last model is "reception with modification IASS/IFRSs" or convergence by moving local Generally Accepted Accounting Principles (GAAP) towards IFRS (partial convergence). Among three methods, at this time, the last model is suitable to Vietnamese circumstances.

\section{Conclusion}

The study summarized briefly history and development of Vietnamese accounting law and accounting standards from 1986 to present. Simultanously, the study cites the relationship between the development of economic activities and the accounting reformation in Vietnam during that period. A part from that, the study also analyze the role of each component in Vietnamese accounting system such as accounting law, decree, accounting standard, decision and circular. Beside that, the study describes the experience in accounting convergence from members of AEC. In which, there are only three countries which enacted their national accounting standards based on IASs/IFRSs and are almost unchanged with new features of IASs/IFRSs. Therefore, it can be said that 
most of AEC members converge with IASs/IFRSs. As such, in the trend of international accounting integration, Vietnam can choose one of three models to adopt IASs/IFRSs, namely, (1) convergence by applying direct IFRS (full or near-full convergence), (2) convergence by moving local GAAP towards IFRS (partial convergence) and (3) convergence by alignment with IFRS in reciprocal way.

\section{References}

Baker, C. R., \& Barbu, E. M. (2007). Trends in research on international accounting harmornization. The International Journal of Accounting, 42, 272-304. https://doi.org/10.1016/j.intacc.2007.06.003

Chu, T. (2004). Accounting changes in a transition economy: The case of Vietnam. University of Wollongong Thesis Collection.

Dao, M. H., \& Dang, P. M. (2017). Chuẩn mực báo cáo tài chính quốc tế (IFRS) cơ hội và thách thức khi áp dụng tại Việt Nam/International Financial Reporting Standards (IFRS) opportunities and challenges when applied in Vietnam (in $\quad$ Vietnamese). Retrieved from http://ifrsvietnam.vn/tin-tuc/nghien-cuu-trao-doi-72/chuan-muc-bao-cao-tai-chinh-quoc-te-ifrs-co-hoi-va-thach-th uc-khi-ap-dung-tai-viet-nam-200.html

DezanShiza \& Associates. (2016). Navigating VAS: A Guide to Vietnamese Accounting Standards. Vietnam Briefing. Retrieved from https://www.eurochamvn.org/sites/default/files/uploads/pdf/VB\%202016\%203.pdf

Ernst, \& Young. (2014). Application of International Financial Reporting Standards (IFRS) and International Standards on Auditing (ISAs) in ASEAN. Retrieved from http://www.fap.or.th/images/column_1370855183/IFRS_ISAs\%20Adoption-2.pdf

Huynh, T. D., Doan, D. V., \& Gong, G. M. (2012). Vietnamese Accounting System Reform - Review and Prospect. Australian Journal of Basic and Applied Sciences, 6(9), 629-651.

Micheline, R., \& Nguyen, C. P. (2007). The new system of business accounting in Vietnam: An empirical evaluation. Chaire d'information financiere et organisationnelle [Chair of financial and organizational information]. Retrieved from http://www.cifo.uqam.ca/publications/pdf/2007-03.pdf

Ministry of Finance (MOF). (1993). Circular No.84-TC/CDKT dated October $23^{\text {rd }} 1993$ guidelines the implementation of accounting activities in foreign-invested enterprises (in Vietnamese).

Ministry of Finance (MOF). (1995). Decision No.1141-TC/QD/CDKT dated November $1^{\text {st }} 1995$ promulgating the enterprises' accounting regime for state businesses and other types of businesses (in Vietnamese).

Ministry of Finance (MOF). (1996). Decision No.1177/TC/QD/CDKT dated December $23^{\text {rd }} 1996$ on accounting regime for small and medium entities (in Vietnamese).

Ministry of Finance (MOF). (2001). Decision No.149/2001/QD-BTC of Minister of Finance dated December $31^{\text {st }} 2001$ on promulgating and announcing 04 VASs (stage 1) (in Vietnamese).

Ministry of Finance (MOF). (2002). Decision No.165/2002/QD-BTC of Minister of Finance in December $31^{\text {st }}$ 2002 on promulgating and announcing 06 VASs (stage 2).

Ministry of Finance (MOF). (2003). Decision No.234/2003/QD-BTC of Minister of Finance in December $30^{\text {th }}$ 2003 on promulgating and announcing 06 VASs (stage 3).

Ministry of Finance (MOF). (2005a). Decision No.12/2005/QD-BTC of Minister of Finance in February $15^{\text {th }}$ 2005 on promulgating and announcing 06 VASs (stage 4).

Ministry of Finance (MOF). (2005b). Decision No.100/2005/QD-BTC of Minister of Finance in December $28^{\text {th }}$ 2005 promulgating and announcing 04 VASs (stage 5).

Nguyen, A. T., \& Guangming, G. (2012). Vietnamese Accounting Reform and International Convergence of Vietnamese Accounting Standards. International Journal of Business and Management, 7(10), 26-36. https://doi.org/10.5539/ijbm.v7n10p26

Nguyen, T. H. (2014). VAS - so sánh với IAS/IFRS/ VAS - Compare to IAS/IFRS (in Vietnamese). Journal of Science Technology \& Food, 4, 78-87.

Nguyen, T.T.T. (2017). Phát triển con người của Việt Nam sau 30 năm đổi mới: Thành tựu và Hạn chế (in Vietnamese)/Vietnam's human development after 30 years of renewal: Achievements and Constraints (pp. 87-98). Retrieved from http://www.kas.de/wf/doc/kas_48064-1522-1-30.pdf?170301091959

Nguyen, X. H. (2015). Overview of Vietnamese Accounting System Since 1975 and the Process of Vietnam's Convergence to IFRS. Journal of Modern Accounting and Auditing, 11(5), 260-268. 
https://doi.org/10.17265/1548-6583/2015.05.002

Phan, T. A. D. (2016). Kế toán kiểm toán các quốc gia ASEAN: Chuẩn bị cho việc gia nhập cộng đồng kinh tế ASEAN/Accounting and auditing of ASEAN countries: Preparation for joining the ASEAN Economic Community (in Vietnamese). Journal of Banking Science and Training, 167, 11-15.

Phi, T. D. H. (2014). The Vietnam Accounting System: History and Development. Essays on economics Komazawa University, 46(2), 73-91.

Puxty, A. G., Willmott, H. C., Cooper, D. G., \& Lowe, T. (1987). Modes of regulation in advanced capitalism: locating accountancy in four countries. Accounting, Organizations and Society, 12(3), 273-291. https://doi.org/10.1016/0361-3682(87)90041-9

PwC Vietnam News Brief. (2016). Accounting Law 2015. PwC Vietnam NewsBrief. Retrieved from https://www.pwc.com/vn/en/publications/2016/pwc-vietnam-newsbrief-accounting-law-2015-en.pdf

State Council. (1988). Ordinance on Accounting and Statistics dated May $10^{\text {th }} 1988$ (in Vietnamese).

Thanh, M. V. B. (2011). A study of the development of accounting in Vietnam. Doctor of Philosophy (PhD), Accounting, RMIT University.

The Government. (2004). Decree No.128/2004/ND-CP dated 31 ${ }^{\text {st }}$ May 2004 guiding the Accounting Law No. 03/2003/QH11 applicable in the field of state accounting.

The Government. (2004). Decree No.129/2004/ND-CP dated May $31^{\text {st }} 2004$ guiding the Accounting Law No.03/2003/QH11 applicable in business activities.

The Government. (2016). Decree No.174/2016/ND-CP dated December $30^{\text {th }} 2016$ detailed some articles of the Accounting Law No. 88/2015/QH13.

The IFRS Foundation. (2017). Retrieved from http://www.ifrs.org/

The National Assembly. (2003). Accounting Law No.03/2003/QH11: Accounting Law dated June $17^{\text {th }} 2003$.

The National Assembly. (2015). Accounting Law No.88/2015/QH13: Accounting Law dated $30^{\text {th }}$ November 2015.

The Prime Minister. (2013). Decision No.480/QD-TTg dated March $18^{\text {th }} 2013$ approving the accounting and audit strategy up to 2020 with a vision toward 2030 (in Vietnamese).

Tran, T. T. (2015). The economics of onion storage in Kinh Mon district, Haiduong province, Vietnam. Unpublished Master's Thesis, Department of Agricultural and Applied Economics, College of Economics and Management, University of the Philippines Los Banos.

Worldbank Database. (2017). Retrieved from https://data.worldbank.org/country/vietnam?view=chart

\section{Copyrights}

Copyright for this article is retained by the author(s), with first publication rights granted to the journal.

This is an open-access article distributed under the terms and conditions of the Creative Commons Attribution license (http://creativecommons.org/licenses/by/4.0/). 